\title{
Velvet Ants, Mutillidae (Insecta: Hymenoptera) ${ }^{1}$
}

Jeffrey C. Hertz ${ }^{2}$

\section{Introduction}

Insects in the family Mutillidae are often referred to as "velvet ants" because female members of the family lack wings and have coarse setae that cover most of their body, making them resemble hairy ants. To the surprise of most people, mutillids are not ants at all - they are wasps.

\section{Distribution}

The Mutillidae family contains approximately 230 genera/subgenera and about 8,000 species worldwide (Manley and Pitts 2002). Approximately 435 species occur in mostly arid areas of the southern and western parts of North America (Triplehorn and Johnson 2005). Fifty species in seven genera are found in Florida (Table 1) (Krombein 1979).

\section{Biology}

All Mutillidae are solitary parasitoid wasps that mostly attack mature larvae or pupae of other solitary Hymenoptera. However, velvet ants have been observed targeting non-feeding stages of Diptera, Coleoptera, Lepidoptera, Blattodea, and even some eusocial Hymenoptera (Brothers et al. 2000).

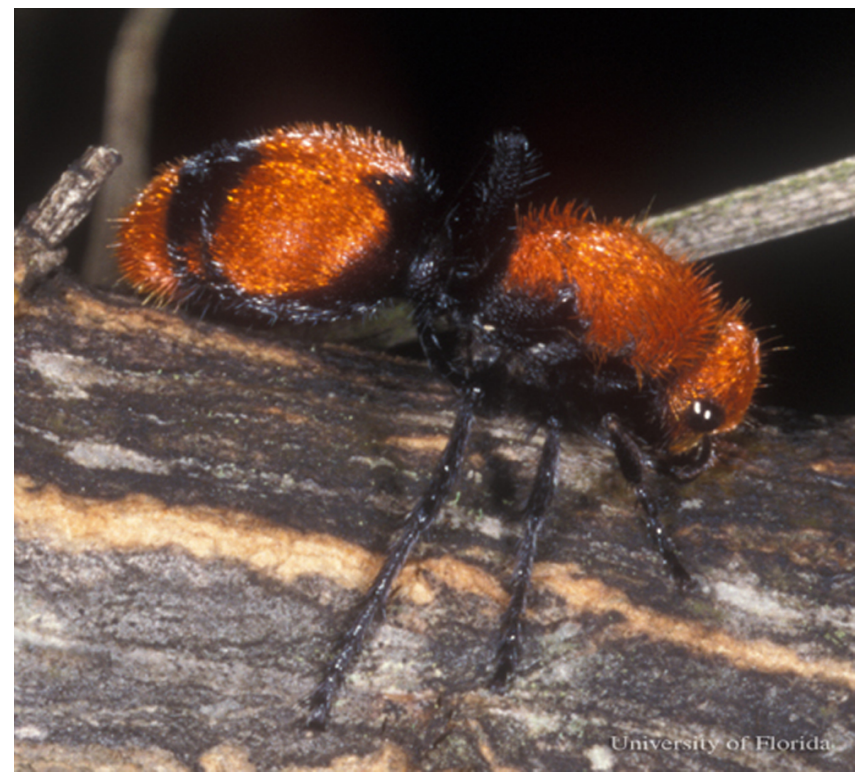

Figure 1. Adult female "cow killer," Dasymutilla occidentalis occidentalis (Linnaeus), a velvet ant. Credits: Lyle Buss, University of Florida

Finding a matching reproductive pair can be difficult, if not impossible for some species, because of the extreme sexual dimorphism displayed within this family. Color patterns and the relative body size of the two sexes of the same species can be very different, making it very difficult to relate one sex with the other (Mickel 1928).

1. This document is EENY-378 (IN717), one of a series of the Entomology and Nematology Department, Florida Cooperative Extension Service, Institute of Food and Agricultural Sciences, University of Florida. Original publication date March 2007. This document is also available as a Featured Creature at http://creatures.ifas.ufl.edu/. Please visit the EDIS Web Site at http://edis.ifas.ufl.edu.

2. Jeffrey C. Hertz, graduate student (P.G. Koehler, advisor) Entomology and Nematology Department, Institute of Food and Agricultural Sciences, University of Florida, Gainesville, FL 32611.

The Institute of Food and Agricultural Sciences (IFAS) is an Equal Opportunity Institution authorized to provide research, educational information and other services only to individuals and institutions that function with non-discrimination with respect to race, creed, color, religion, age, disability, sex, sexual orientation, marital status, national origin, political opinions or affiliations. U.S. Department of Agriculture, Cooperative Extension Service, University of Florida, IFAS, Florida A. \& M. University Cooperative Extension Program, and Boards of County Commissioners Cooperating. Larry Arrington, Dean 


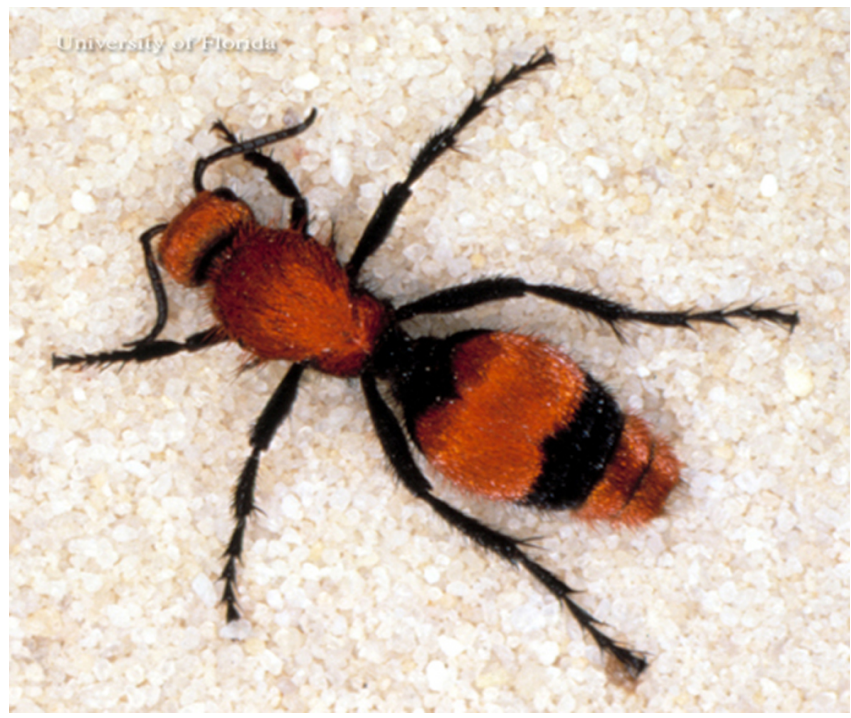

Figure 2. Dorsal view of adult female "cow killer," Dasymutilla occidentalis occidentalis (Linnaeus), a velvet ant. Credits: James Castner, University of Florida

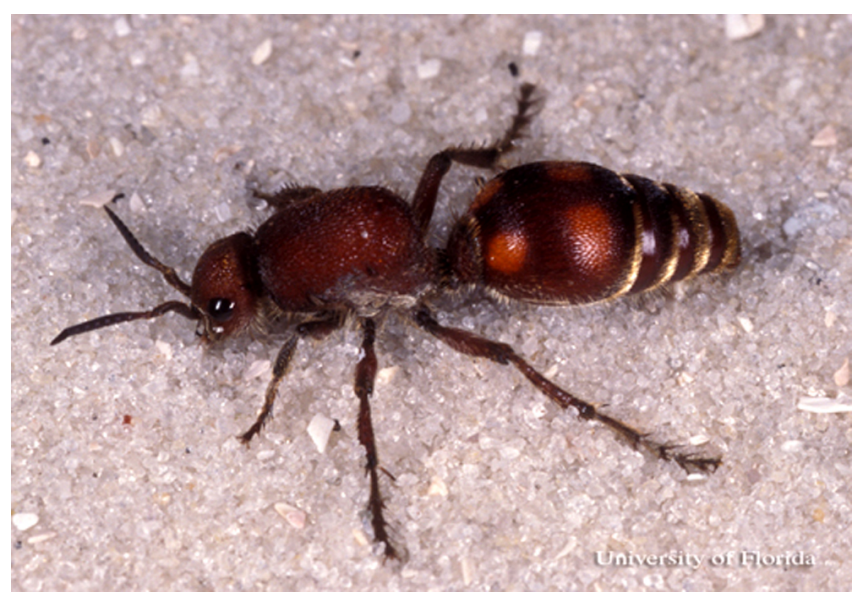

Figure 3. Adult female Dasymutilla sp., a velvet ant. Credits: Lyle Buss, University of Florida

In Florida, male Mutillidae are frequently larger (heavier) than the females. One study in south-central Florida found that in seven out of 13 species, the males were heavier than the females. The remaining six species either showed comparable sizes between the male and female (3) or the female was larger than the male (3) (Deyrup and Manley 1986).

Biological data is very scarce and differences obviously exist between genera and species, especially with regards to their life cycles and development, but the following has been reported for most Mutillidae. Females have the difficult job of locating potential hosts. Suitable hosts may be difficult to find for several reasons including: concealment, low population densities when solitary

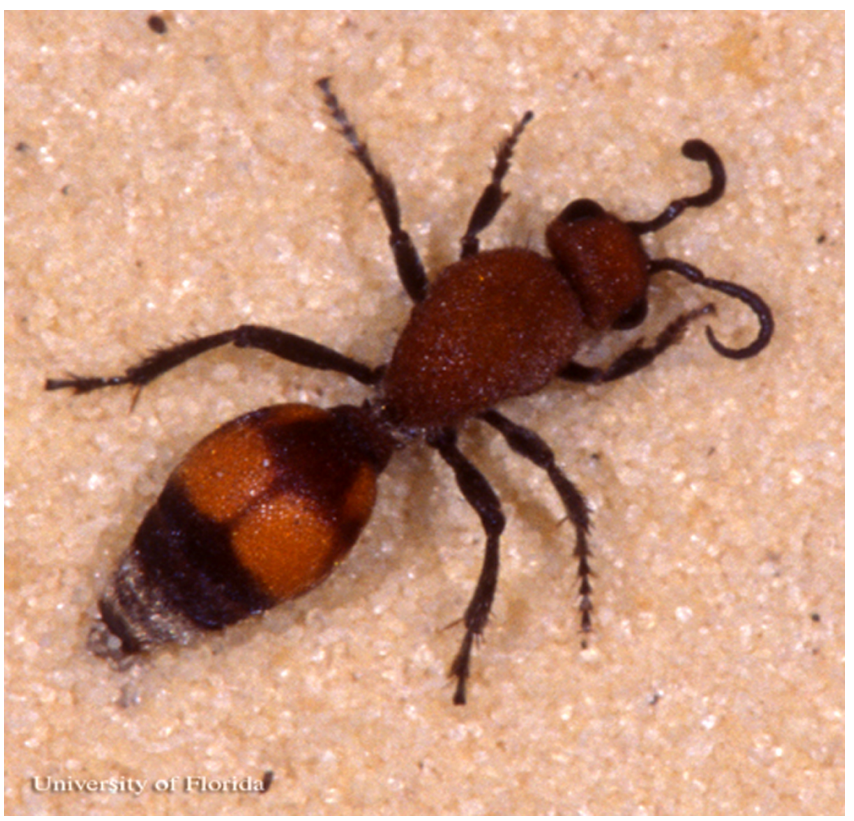

Figure 4. Dorsal view of adult female Dasymutilla sp., a velvet ant. Credits: Lyle Buss, University of Florida

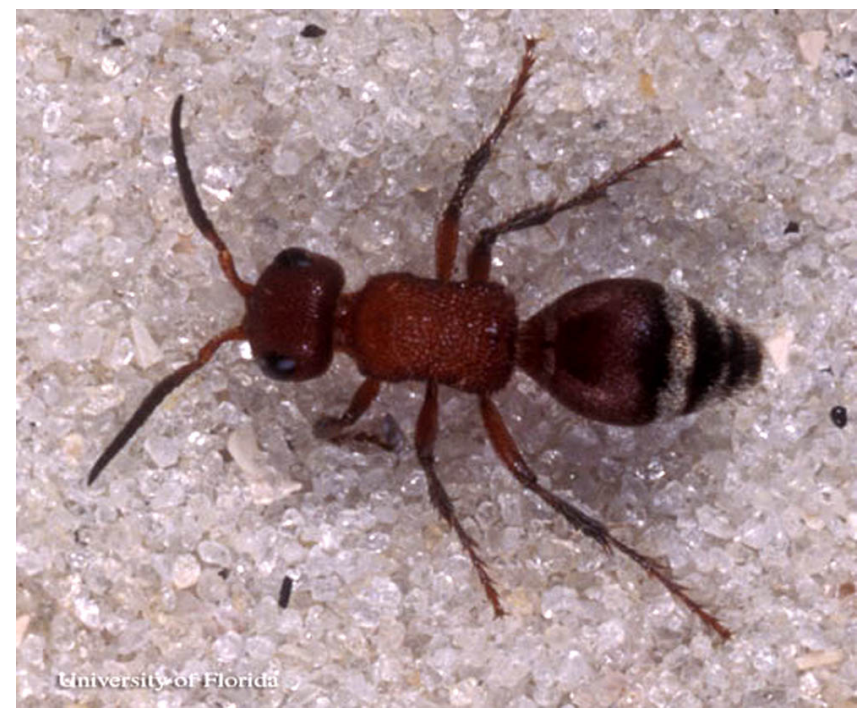

Figure 5. Dorsal view of an adult female Timulla sp., a velvet ant. Credits: Lyle Buss, University of Florida

and lastly, if the hosts are eusocial, they will be heavily defended. Once a host is located, female velvet ants parasitize the "hard" life stages (i.e., hardened pre-pupae, pupae, ootheca, eusocial cells, and cocoons) of the hosts and the emerging velvet ant larvae are essentially ectoparasites of those life stages. (Brothers et al. 2000). Once development is completed, adults leave the nest and seek a mate. 


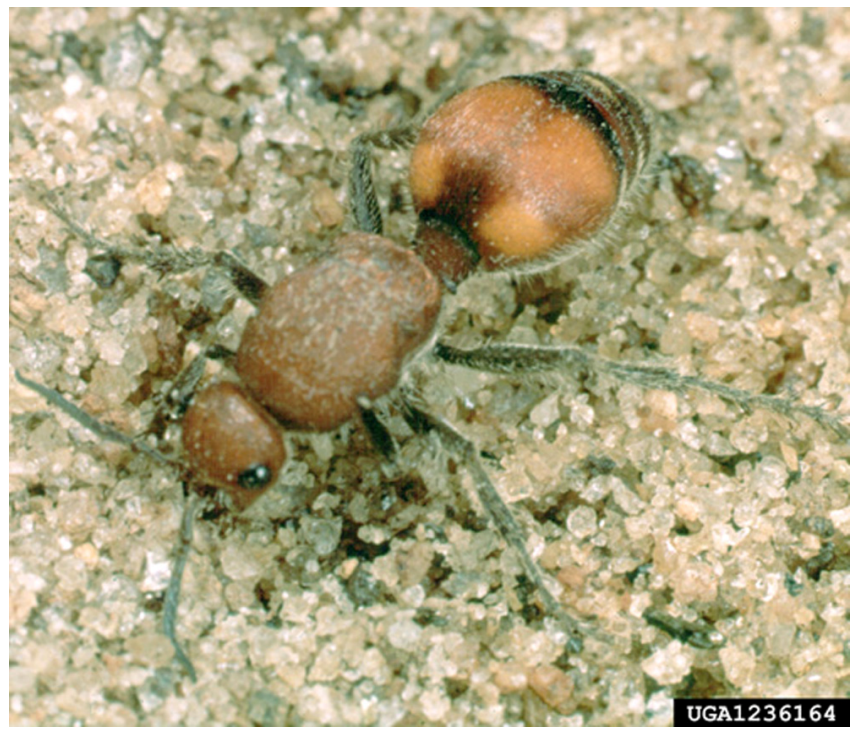

Figure 6. Dorsal view of an adult female velvet ant. Credits: Clemson University, www.forestryimages.org

\section{Identification}

All female Mutillidae are wingless and resemble ants. They can easily be differentiated from ants by the lack of petiole nodes, which are present on all ant species. In addition, the mesosomatic (thoracic) segments are completely fused and have at most two segments. The metasoma (abdomen) contains six visible terga (dorsal surface of any body segment) and a "felt line" of dense, closely appressed hairs is located laterally on the second metasomatic tergum (except for the genus Ephuta) (Manley and Pitts 2002, Triplehorn and Johnson 2005).

Unlike the female, the male meso- and metathorax are not fused and they have three mesosomatic segments. Their metasomal region contains seven visible terga and a felt line is also on the lateral margin of tergite II. All male Mutillidae found in Florida normally have large wings lacking jugal lobes and forewings with the $\mathrm{M}$ and $\mathrm{Cu} 1$ veins ending far from the apical margin (Manley and Pitts 2002).

\section{Keys to Florida Genera}

The most recently published key to genera and subgenera was issued by Manley and Pitts (Manley and Pitts 2002). Conclusions and pictures contained within this key were derived directly from the this publication, but only for genera found in Florida.

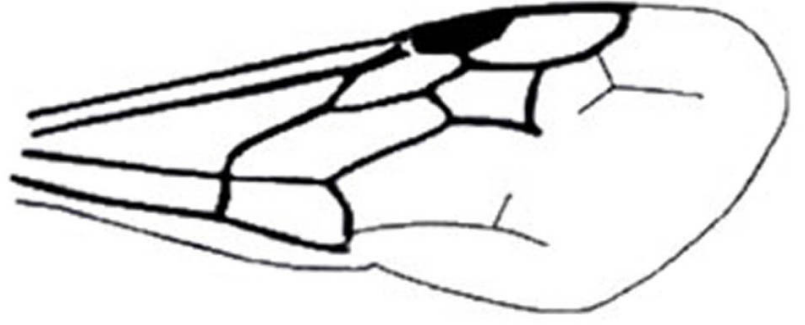

Figure 7. Anterior wing of subfamily Sphaeropthalminae. Note: lacks jugal lobes. Credits: Manley and Pitts 2002

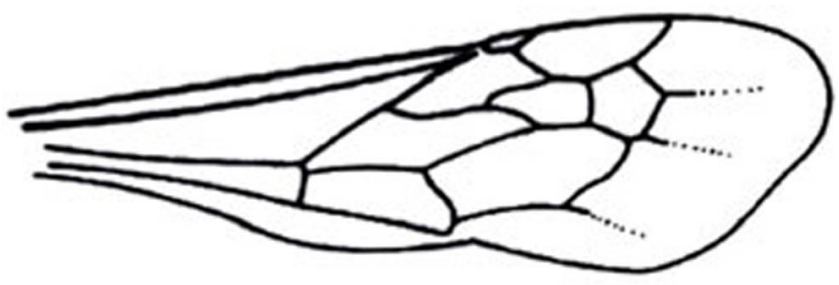

Figure 8. Anterior wing, subfamily Mutillinae, with pterostigma membranous or absent. Credits: Manley and Pitts 2002

\section{Female Specimens}

1. Metasomal segment I completely sessile with second (without petiole) ..... 2

1'. Metasoma petiolate or at most subsessile, with definite constriction between first two segments (Figure 9) ....5

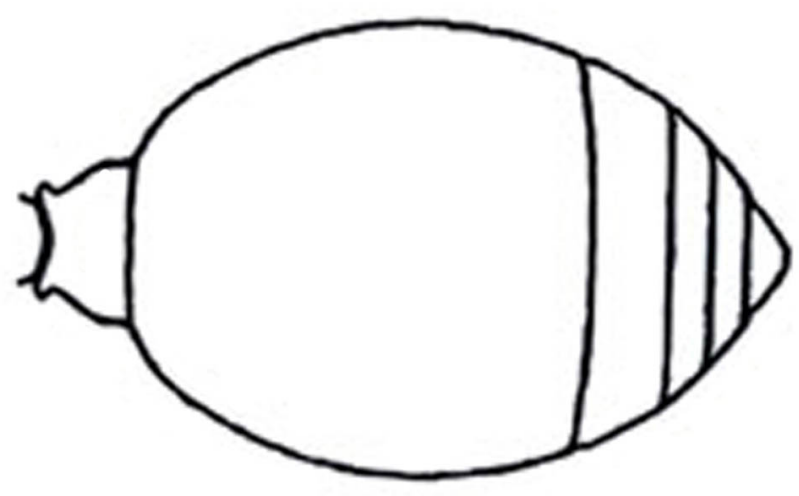

Figure 9. Dorsal view of abdomen with petiolate metasoma. Credits: Manley and Pitts 2002

2. Eyes strongly ovate; mesosoma long, rectangular, generally narrowed medially (Figure 10); tergite II generally maculated with two spots or lines of pale setae ..... Timulla spp.

2 '. Eyes circular to slightly ovate; mesosoma otherwise (short, rectangular or narrowed posteriorly, 
if narrowed medially, mesosoma pyriform not rectangular); tergite II not maculated with spots of pale setae .... 3

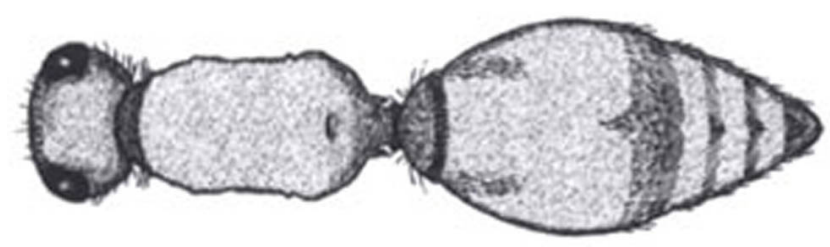

Figure 10. Dorsal view of long, rectangular mesosoma of Timulla spp. Credits: Manley and Pitts 2002

3. Head, in dorsal view, less than twice the width of mesosoma (Figure 11); pygidium usually with lateral carinae mesosoma narrowed medially; head not dentiform (toothed); if hypostomal teeth present they are not prominent, nor bent apically; posterolateral angles of head, usually not strongly carinate (ridged) .... . Pseudomethoca

3'. Mesosoma as wide or wider than head in dorsal view, rectangular without fine carina between pronotum and mesonotum (Figure 12); eyes slightly ovate; mandible ventrally toothed or not; sternal felt line absent; plumose setae present or absent; integument visible, usually sparsely covered with appressed and erect simple setae pygidium variable . . $\ldots 4$

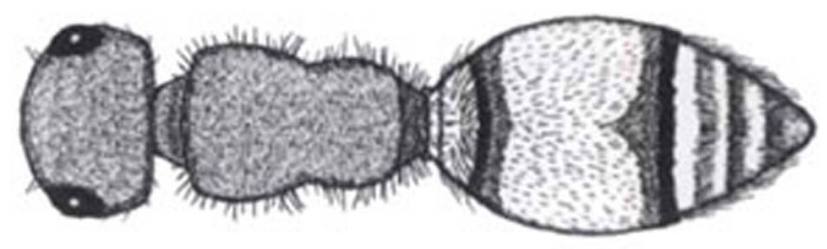

Figure 11. Dorsal view of Pseudometheca simillima (Smith). Note: head less than twice the width of mesosoma. Credits: Manley and Pitts 2002

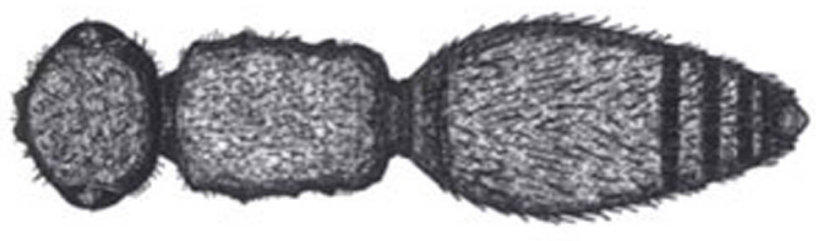

Figure 12. Dorsal view of rectangular mesosoma of Photomorphus spp. Note: as wide or wider than head. Credits: Manley and Pitts 2002
4. Pygidium dull, shagreened (rough), with parallel carinae only on basal two-thirds or less ..... Photomorphus, subgenus Photomorphina

4'. Pygidium smooth and shiny, with complete parallel carinae on disk .... . Photomorphus, subgenus Photomorphus

5. Felt lines absent on metasomal tergite II; petiole short, transverse, parallel-sided (Figure 13); eyes distinctly ovate; a band of silvery, dense, pubescence present at apex of petiole and metasomal segment II; small; densely punctuate (subfamily Mutillinae, tribe Ephutini) .... . Ephuta

5'. Felt lines present on metasomal tergite II; petiole not transverse or parallel sided; eyes circular to slightly ovate; other characters variable . . . 6

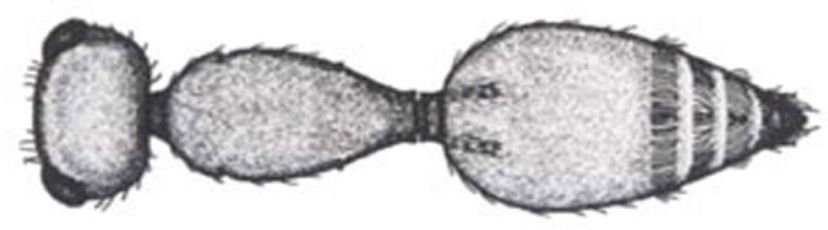

Figure 13. Dorsal view of short, parallel-sided petiole of Ephuta spp. Credits: Manley and Pitts 2002

6. Plumose setae limited to area of short dense white setae on dorsum of petiole, and apical fringe of tergite II (Figure 14); pygidial area undefined laterally by carinae; genal carina absent; flagellomere II greater than $1.75 x$ length of first; antennal scrobe distinctly carinate dorsally; propodeum elongate .... . Sphaeropthalma, subgenus Sphaeropthalma

6'. Plumose setae totally absent . . . . 7

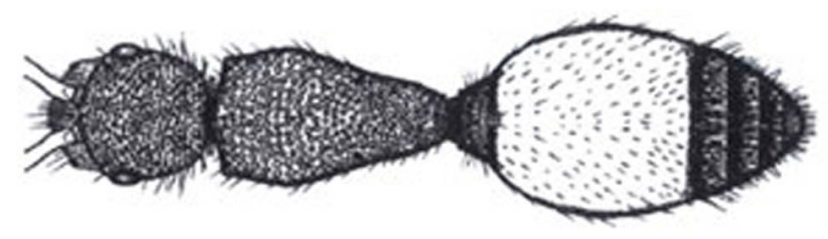

Figure 14. Dorsal view of apical fringe of tergite II of Sphaeropthalma Sphaeropthalma pensylvanica (Lepeletier). Credits: Manley and Pitts 2002

7. Pygidial area well-defined; petiole not diciform (rounded) (Figure 15) . . . . Dasymutilla 
7'. Pygidial area obsolete, not defined laterally; petiole distinctly disciform (Figure 16); Anterior and propodeal spiracles tuberculate (Figure 17) . . . . Lomachaeta

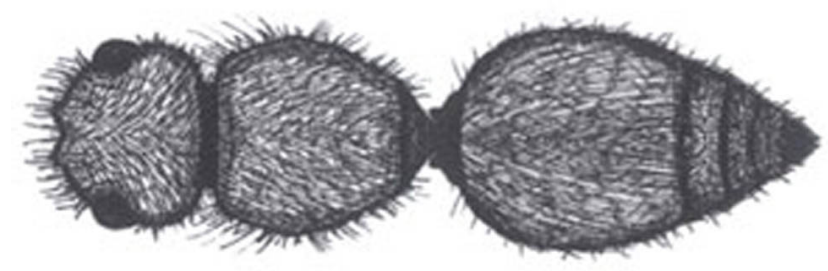

Figure 15. Dorsal view of non-diciform petiole of Dasymutilla spp. Credits: Manley and Pitts 2002

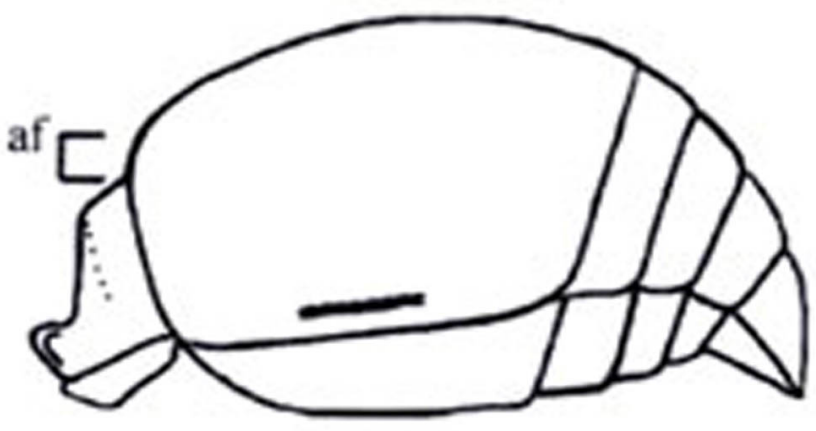

Figure 16. Lateral view of Lomacheata spp. metasoma (af = anterior face). . Credits: Manley and Pitts 2002

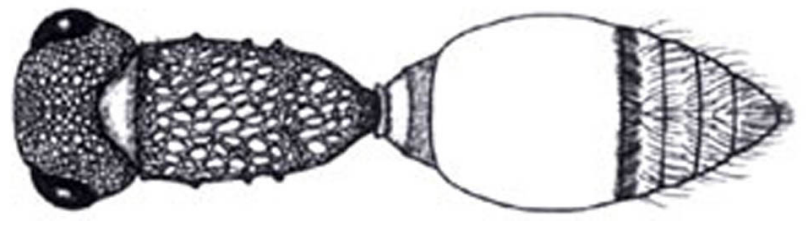

Figure 17. Dorsal view of tuberculate anterior and propodeal spiracles of Lomachaeta variegata. Credits: Manley and Pitts 2002

\section{Male Specimens}

1. Compound eye approximately round, not emarginated, smooth and shiny (Figure 18); pterostigma sclerotized ..... 2

1'. Compound eye with inner margin deeply and sharply emarginated (Figures 19 and 20); pterostigma membranous or absent (Figure 21).... . 6

2. Metasomal segment I completely sessile with second (Figure 22); Felt line present on lateral margin of tergite II only; hypostomal tooth not developed; head less than twice width of mesosoma;

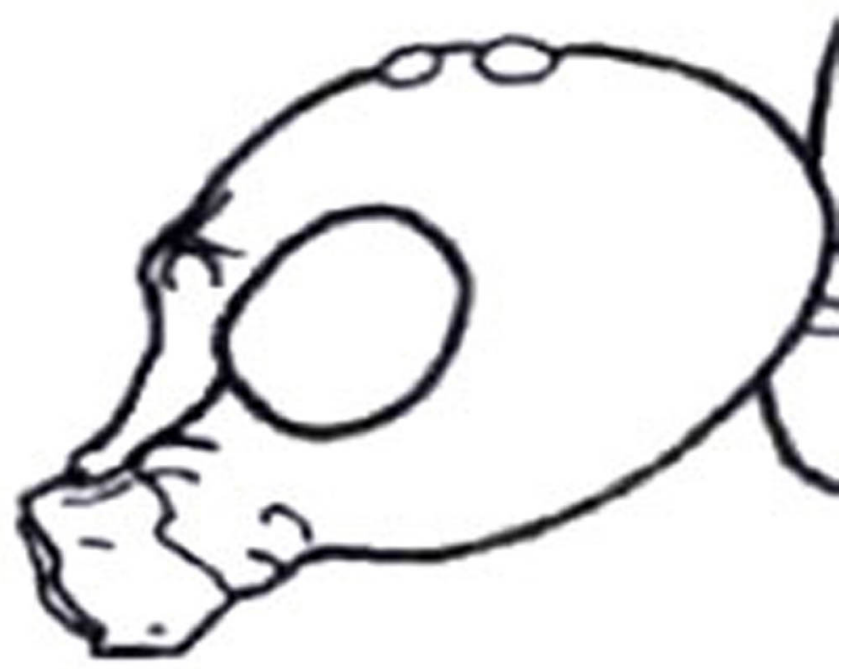

Figure 18. Rounded, not emarginated, compound eye of Photomorphus. Credits: Manley and Pitts 2002

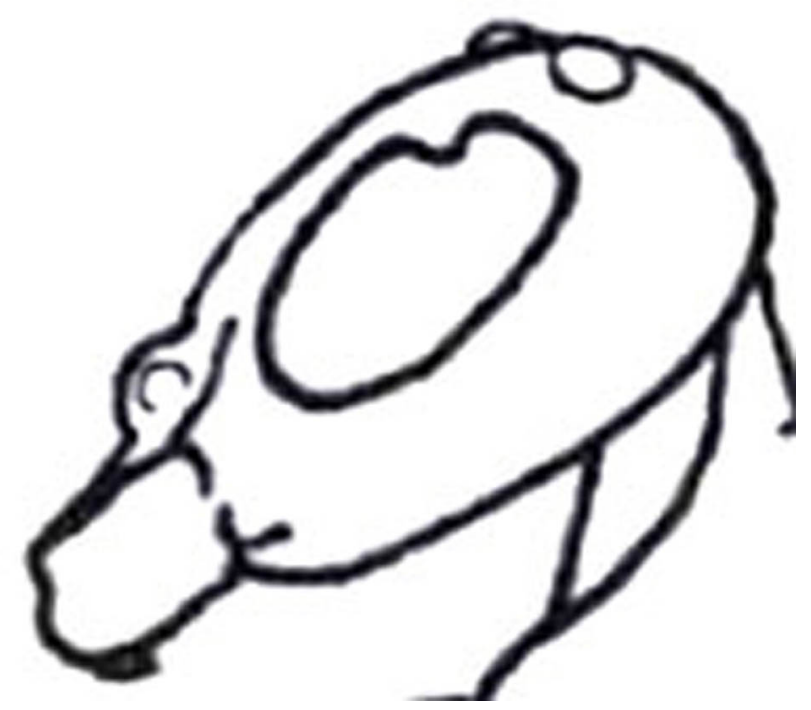

Figure 19. Emarginated compound eye of Timulla dubitata (Smith). Credits: Manley and Pitts 2002

posterolateral angles of head not strongly carinate or dentiform; wings macropterous ..... Pseudomethoca

2'. Metasoma petiolate or at most subsessile, with definite constriction between first two segments (Figure 23) .... 3

3. Felt line present on lateral margin of tergite II and sternite II; ventral mandibular tooth present (Figure 24); mesoscutal notauli present (separates mesoscutum into medial and lateral lobes); flagellomere I longer than wide, not like pedicel; hypopygium (last visible abdominal sterum) normal, rounded, lateral margins not carinate or dentifrom; 


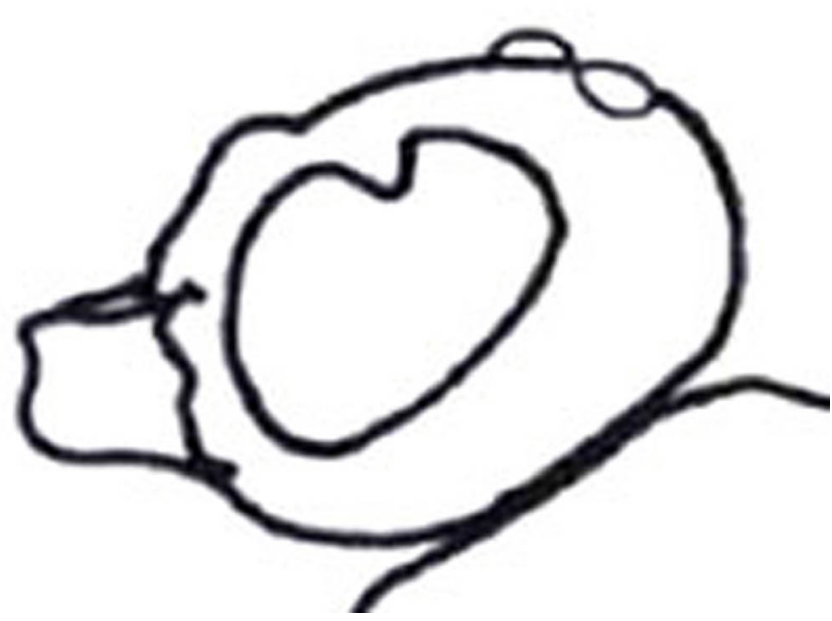

Figure 20. Emarginated compound eye of Ephuta stenognatha Schuster. Credits: Manley and Pitts 2002

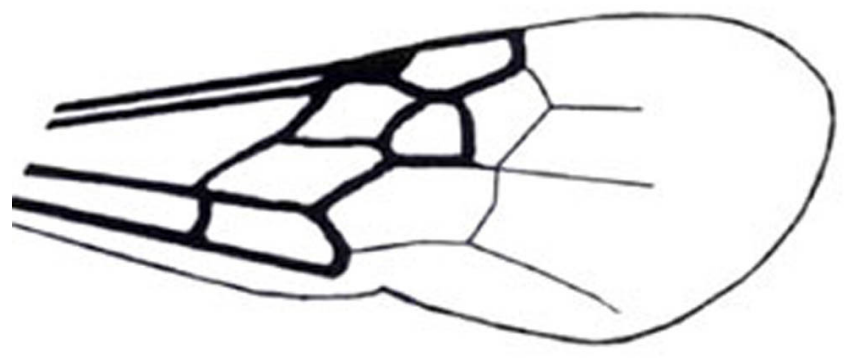

Figure 21. Anterior wing with membranous or absent pterostigma. Credits: Manley and Pitts 2002

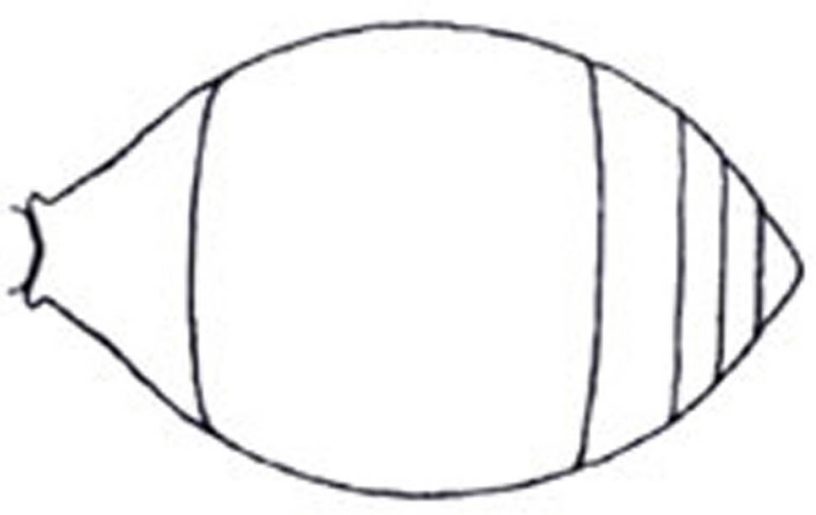

Figure 22. Dorsal view of abdomen with non-petiolate metasoma. Credits: Manley and Pitts 2002

mesosternum with pair of longitudinal to transverse dentate ridges anterior to mesocoxae, closer to procoxae; plumose hairs vestigial or absent . . . . 6

3'. Felt line present on lateral margin of tergite II only; Mesotibia with two spurs; mesotibia cylindrical, not flattened and arcuate; plumose setae present or absent; mesosternum unmodified . . . . 4 4

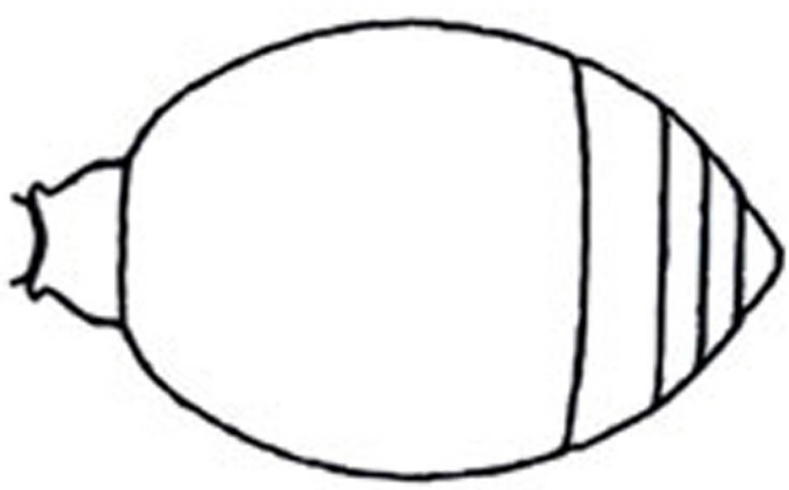

Figure 23. Dorsal view of abdomen with petiolate metasoma. Credits: Manley and Pitts 2002

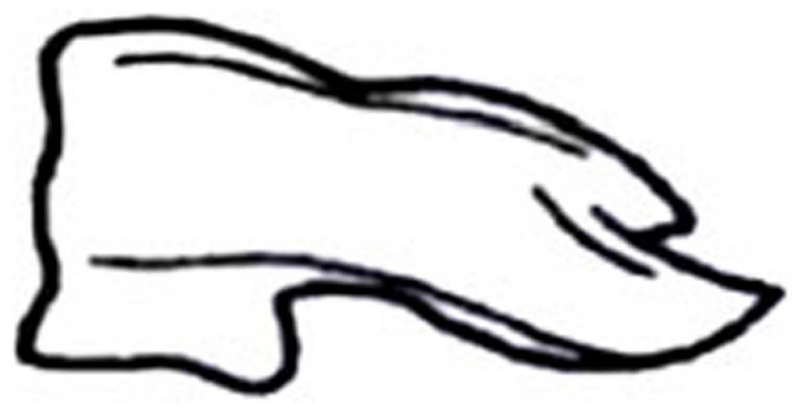

Figure 24. Mandibular tooth of Photomorphus spp. Credits: Manley and Pitts 2002

4. Mandible tridentate apically, broadly emarginated ventrally with small, distinct tooth; eyes and ocelli small, not protuberant, compound eye distinctly separated from mandible, distance from compound eye to posterolateral angle of head distinctly greater than greatest diameter of eye; notauli present, complete; tergites II-V without row of lanceolate (lance-shaped) bristles at distal margin; pterostigma of forewing conspicuous; marginal cell length equal to or slightly longer than stigma; pygidium and hypopygium short, transverse ..... Sphaeropthalma, subgenus Sphaeropthalma

4'. Mandible bidentate or tridentate apically, but not emarginate or toothed ventrally ....5 5

5. Notauli absent; subplumose setae present; tergites II-V with row of lanceolate bristles at distal margin; pterostigma of forewing vestigial, inconspicuous (Figure 25) ..... Lomachaeta

5'. Tergites II-V without row of lanceolate bristles at distal margin; subplumose setae absent; 
wing venation normal, not greatly reduced; pterostigma of forewing conspicuous (Figure 26) ... . . Dasymutilla

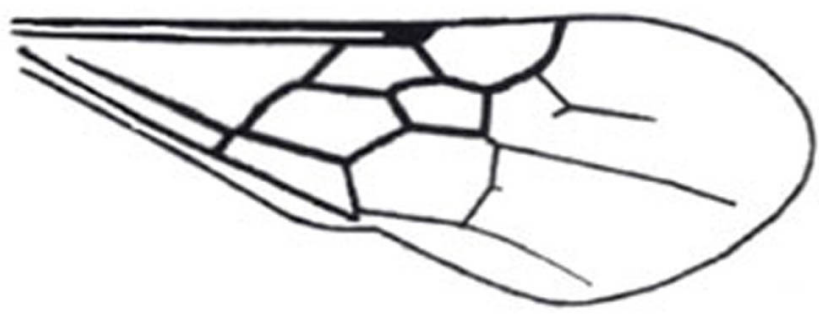

Figure 25. Inconspicuous forewing pterostigma of the genus Lomachaeta. Credits: Manley and Pitts 2002

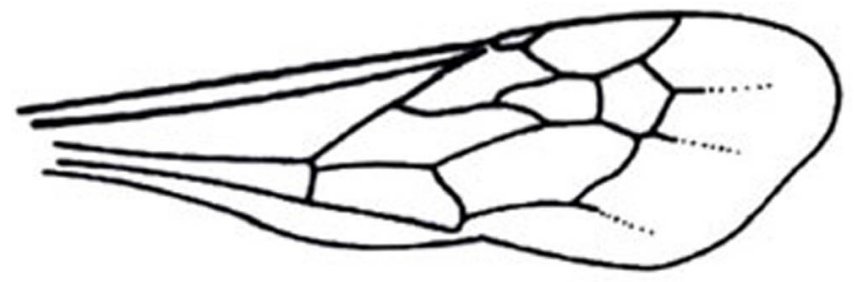

Figure 26. Conspicuous forewing pterostigma.of the genus Dasymutilla. Credits: Manley and Pitts 2002

6. Metasomal segment I sessile with second (Figure 27); humeral angles rounded . . . . Timulla

6'. Metasomal segment I slender, short, parallel-sided, not sessile (Figure 28); humeral angles angulate, sharply produced; small; densely punctuate ..... Ephuta

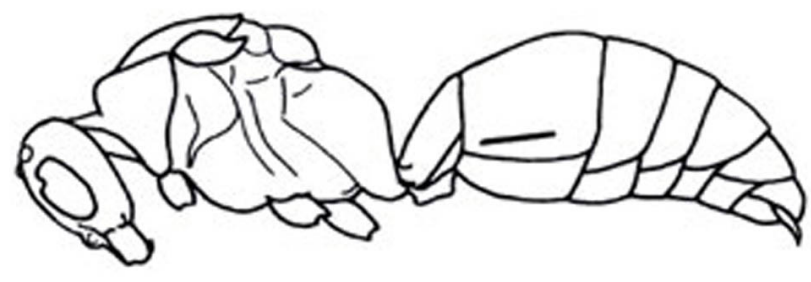

Figure 27. Lateral view of habitus with legs removed, Timulla dubitata (Smith). Credits: Manley and Pitts 2002

7. Mesocoxae approximate; mandible tridentate apically; mentum never produced into a distinct process ..... Photomorphus, subgenus

\section{Photomorphina}

7'. Mesocoxae separated; mandible bidentate apically (Figure 24); mentum distinctly produced as an anterior tubercle (small nodule) or posterior lingulate (tongue-shaped) process . . . . . Photomorphus, subgenus Photomorphus

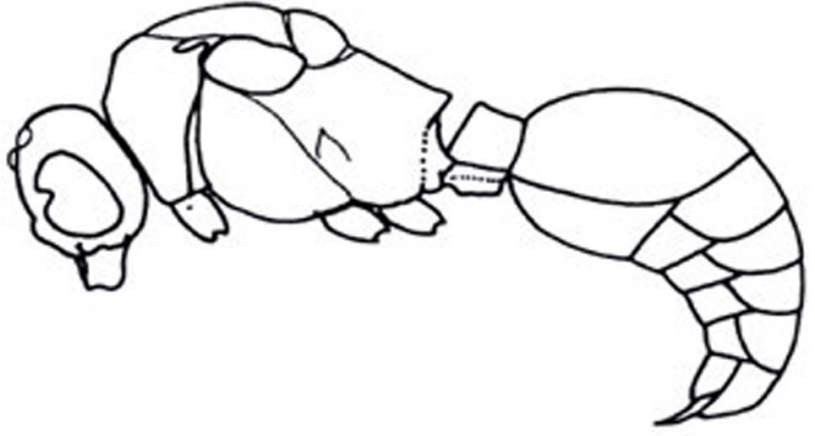

Figure 28. Lateral view of habitus with legs removed, Ephuta stenognatha Schuster. Credits: Manley and Pitts 2002

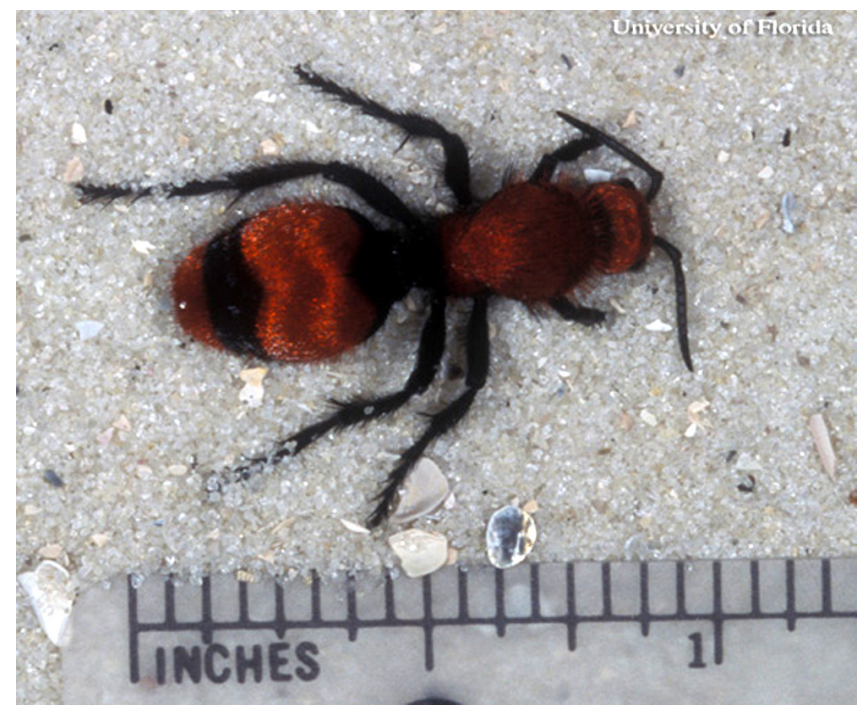

Figure 29. Adult female "cow killer," Dasymutilla occidentalis occidentalis (Linnaeus), a velvet ant. Credits: Lyle Buss, University of Florida

Florida Species

List of Mutillidae species reported from Florida ${ }^{a}$

Tribe: Mutillini

Genus: Timulla Ashmead

barbigera barbigera (Bradley)

compressicornis Mickel

dubitata dubitata (Smith)

dubitatiformis Mickel

euphrosyne Mickel

euterpe (Blake)

ferrugata (Fabricius) 
floridensis (Blake)

leona (Blake)

ornatipennis (Bradley)

rufosignata (Bradley)

vagans rufinota Mickel

\section{Tribe: Ephutini}

Genus: Ephuta Say

battlei battlei Bradley

floridana floridana Schuster

margueritae margueritae Schuster

pauxilla pauxilla Bradley

psephenophila Schuster

puteola (Blake)

sabaliana sabaliana Schuster

slossonae slossonae (Fox)

stenognatha psephenophora Schuster

stenognatha stenognatha Schuster

Subfamily: Sphaeropthalminae

Tribe: Sphaeropthalmini

Genus: Spaeropthalma

subgenus Sphaeropthalma Blake

pensylvanica floridensis Schuster

pensylvanica pensylvanica

(Lepeletier)

Genus: Photomorphus

subgenus Photomorphina Schuster archboldi (Manley and Deyrup) ${ }^{\mathrm{b}}$ spinci (Bradley

Genus: Photomorphus

subgenus Photomorphus Viereck

alogus Viereck banksi (Bradley)

paulus (Bradley)

Tribe: Pseudomethocini

Genus: Pseudomethoca Ashmead

frigida (Smith)

oceola (Blake)

oculata (Banks)

sanbornii aeetis (Fox)

sanbornii sanbornii (Blake)

simillima (Smith)

torrida Krombein

vanduzei Bradley

Genus: Lomachaeta Mickel

hicksi Mickel ${ }^{\mathrm{c}}$

${ }^{\mathrm{a}}$ Unless otherwise noted, this list was compiled from the Catalog of Hymenoptera in America north of Mexico (Krombein 1979)

b (Manley and Deyrup 1987a)

c (Pitts and Manley 2004)

\section{Pest Status and Management}

Mutillidae pose no real threat to humans, livestock, or domesticated animals other than the unfortunate accidental sting associated with unaware victims. Like other stinging insects, only female Mutillidae are capable of stinging. Some species are referred to as "cow killers" or "mule killers," because their sting is said to be painful enough to kill an animal. Despite this assertion, they are not aggressive nor is their venom comparatively toxic. Most female mutillids are so docile, they produce a startle response (an audible stridilation) when provoked to warn potential victims of her sting. The LD50 of their venom when exposed to mice is around $71 \mathrm{mg} / \mathrm{kg}$ body weight which is relatively non-toxic compared to the very toxic harvester ant, Pogonomyrmex maricopa, venom $(\mathrm{LD} 50=0.12 \mathrm{mg} / \mathrm{kg})$ and the moderately toxic honey bee, Apis mellifera, venom $(\mathrm{LD} 50=2.8)$ (Meyer 1996). No control measures are necessary. 


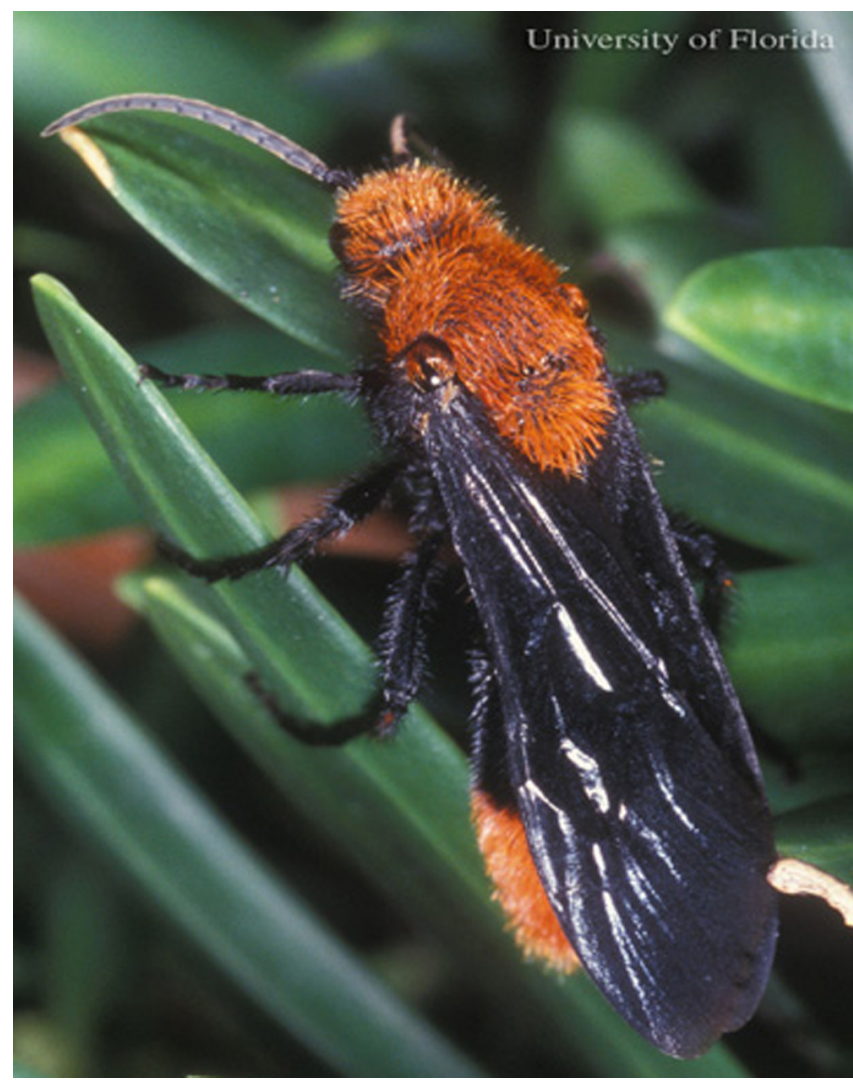

Figure 30. Adult male "cow killer," Dasymutilla occidentalis occidentalis (Linnaeus), a velvet ant. Credits: Jeffrey C. Hertz, University of Florida

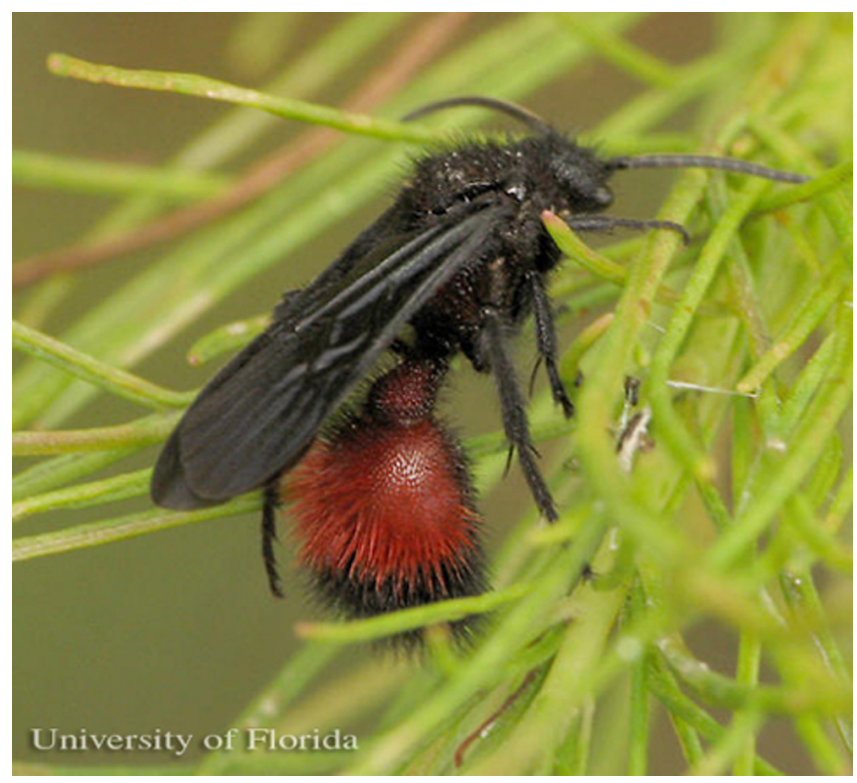

Figure 31. Adult male Dasymutilla nigripes (Fabricius), a velvet ant. Credits: Sean McCann, University of Florida

\section{Acknowledgments}

I sincerely thank Dr. Don Manley, of Clemson University, for providing me the most current

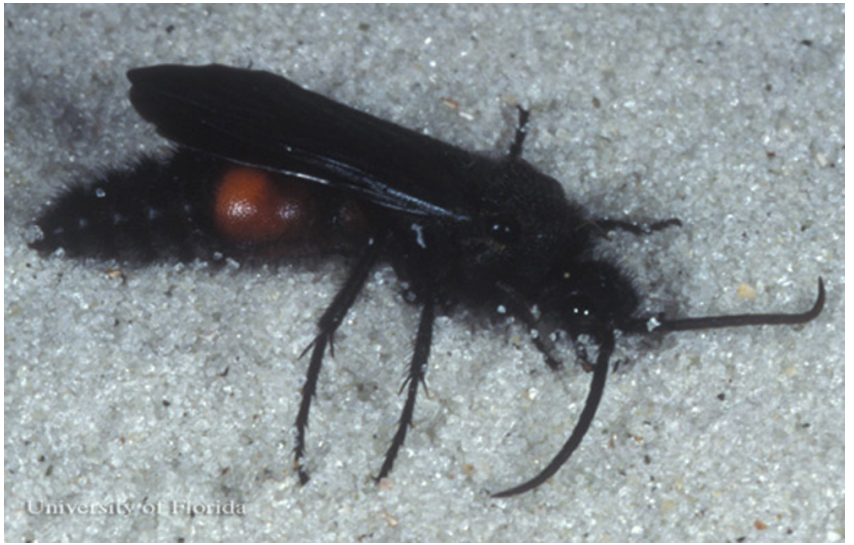

Figure 32. Adult male Dasymutilla sp., a velvet ant. Credits: Lyle Buss, University of Florida

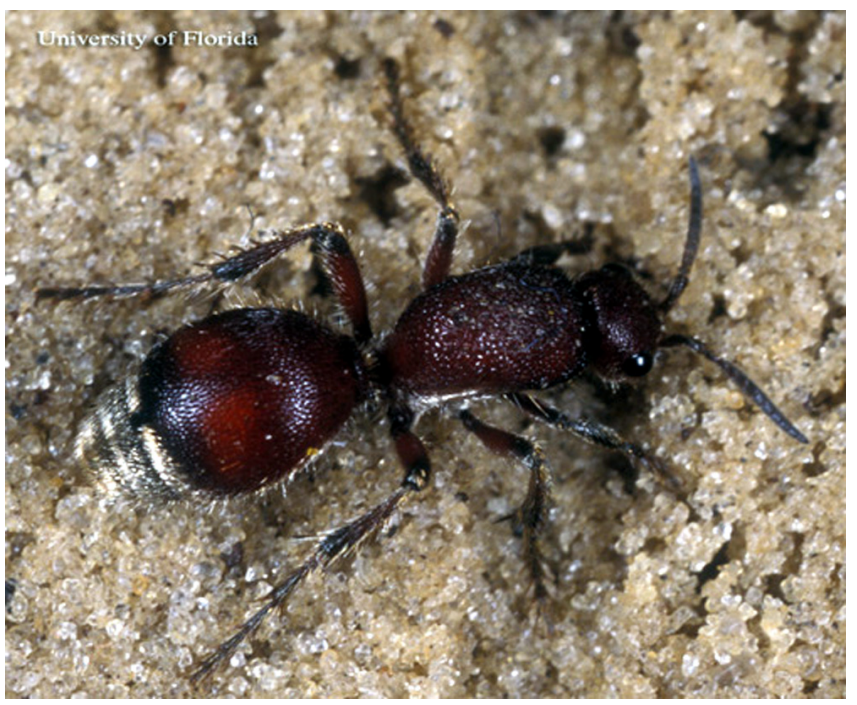

Figure 33. Adult female Dasymutilla sp, a velvet ant. Credits: Charles Schurch Lewallen

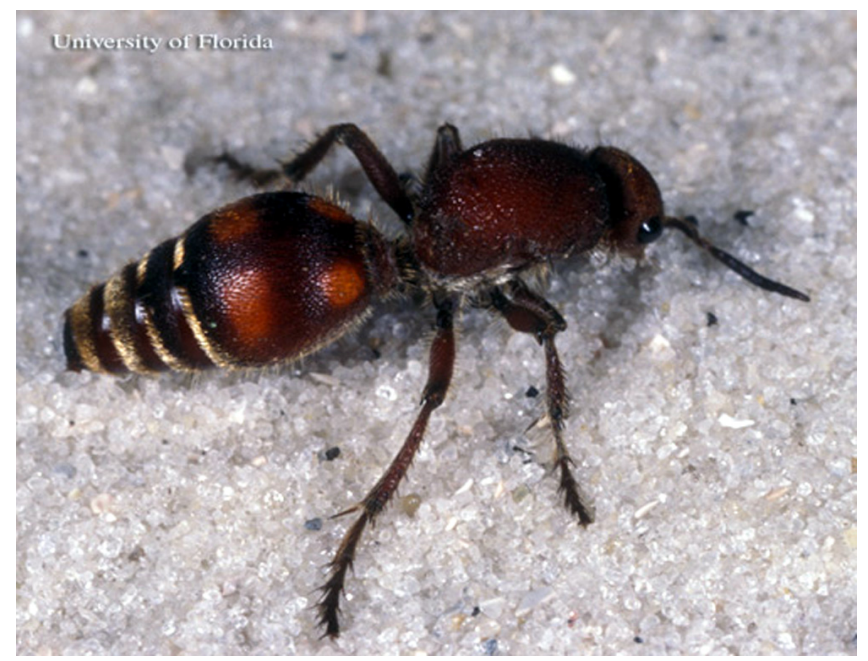

Figure 34. Adult female Dasymutilla sp, a velvet ant. Credits: Lyle Buss, University of Florida

reference literature and taking the time to review this publication. I also thank Dr. Gavin Broad for 


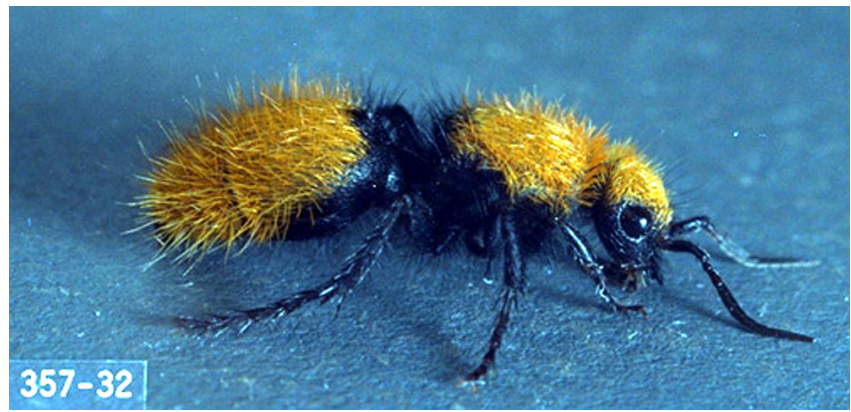

Figure 35. Adult female Dasymutilla sp., a velvet ant. Credits: Ken Gray, Oregon State University

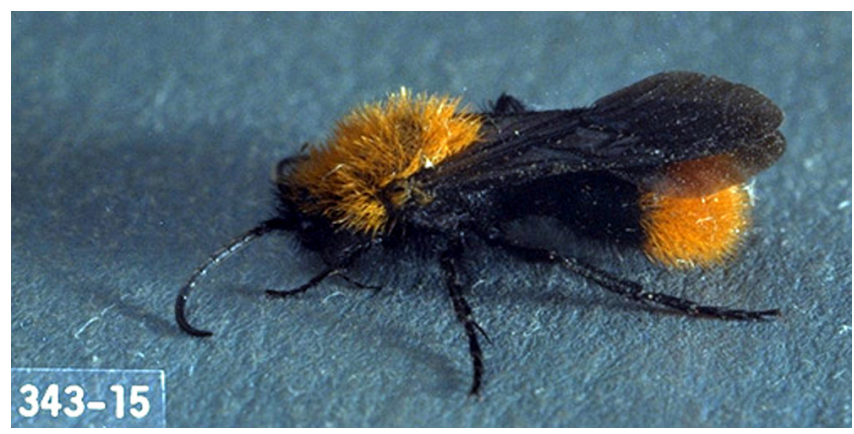

Figure 36. Adult male Dasymutilla sp., a velvet ant. Credits: Ken Gray, Oregon State University

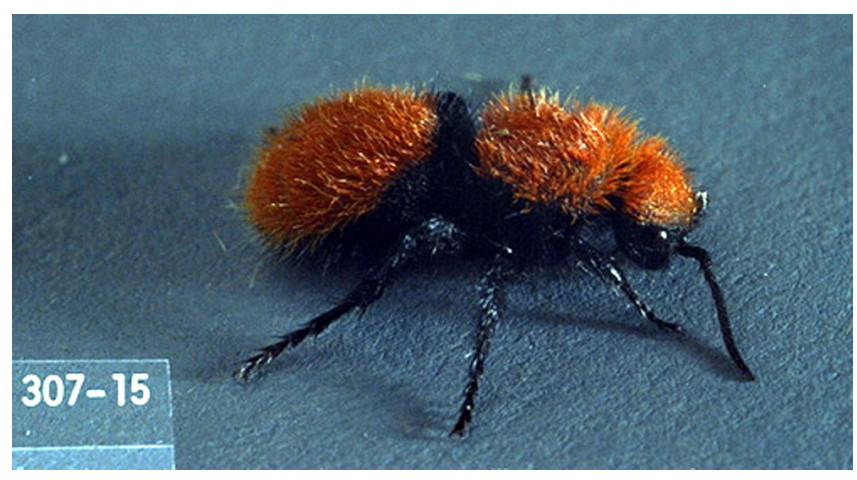

Figure 37. Adult female Dasymutilla sp., a velvet ant. Credits: Ken Gray, Oregon State University

graciously giving me permission to use numerous images previously published in the Journal of Hymenoptera Research.

\section{Selected References}

Brothers DJ, Tschuch G, Burger F. 2000. Associations of mutillidae wasps (Hymenoptera, Mutillidae) with eusocial insects. Insectes Sociaux 47: 201-211.

Deyrup MA, Manley DG. 1986. Sex-biased size variation in velvet ants (Hymenoptera: Mutillidae). Florida Entomologist 69: 327-335.

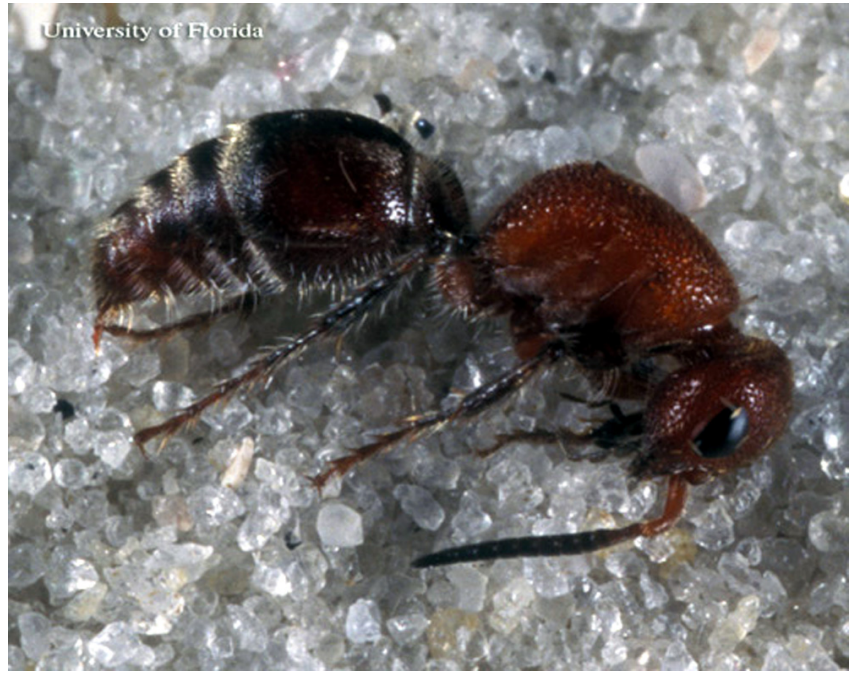

Figure 38. Lateral view of an adult female Timulla sp., a velvet ant. Credits: Lyle Buss, University of Florida

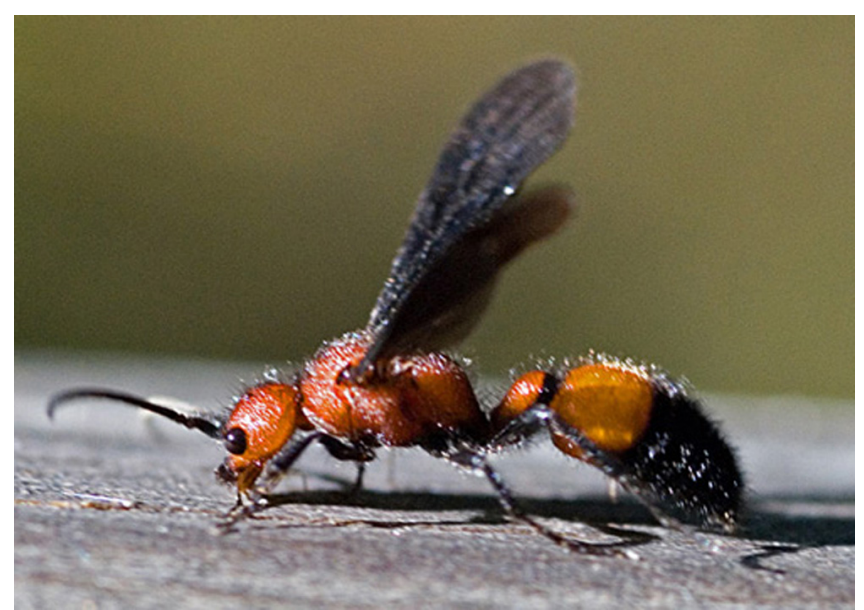

Figure 39. Adult male Sphaeropthalma pensylvanica (Lepeletier), a velvet ant. Credits: Charles Schurch Lewallen

Krombein KV, et. al. 1979. Catalog of Hymenoptera in America north of Mexico. Smithsonian Institution Press, Washington.

Manley DG, Deyrup MA. 1987a. A new species of Dasymutilla (Hymenoptera: Mutillidae) from Florida. Journal of Entomological Science 22: 123-125.

Manley DG, Deyrup MA. 1987b. A new species of Photomorphus (Hymenoptera: Mutillidae) from Florida. Journal of Entomological Science 22: 57-60.

Manley DG, Pitts JP. 2002. A key to genera and subgenera of Mutillidae (Hymenoptera) in America north of Mexico with description of a new genus. Journal of Hymenoptera Research 11: 72-100. 


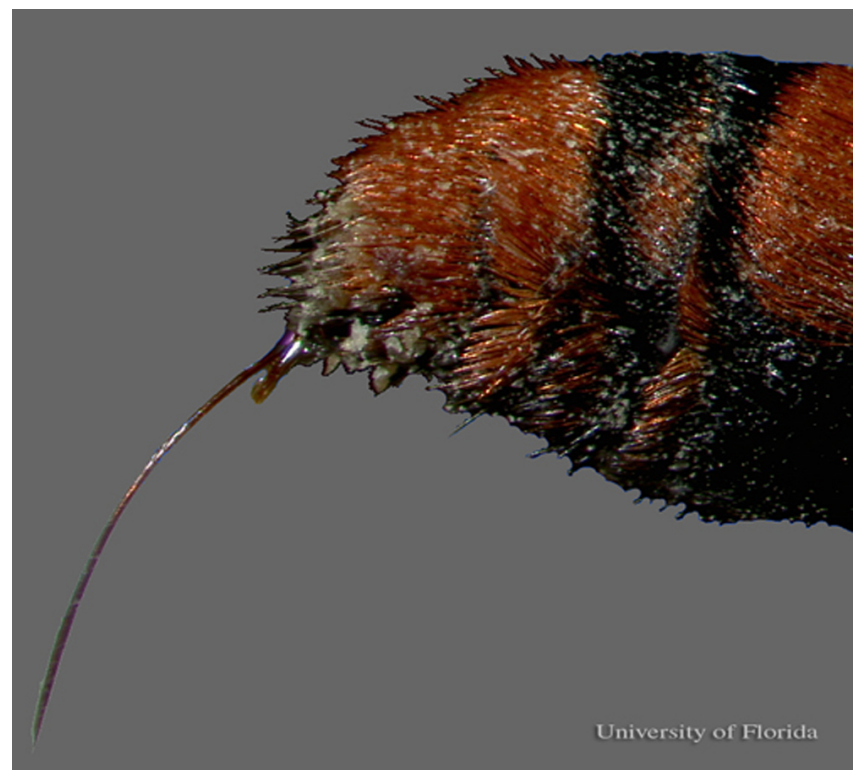

Figure 40. Ovipositor (stinger) of an adult female "cow killer," Dasymutilla occidentalis occidentalis (Linnaeus). Credits: Jeffrey C. Hertz, University of Florida

Meyer WL. 1996. Most toxic insect venom. University of Florida Book of Insect Records. http://ufbir.ifas.ufl.edu/Chap23.htm (22 February 2007).

Mickel CE. 1928. Biological and taxonomic investigations on the mutillid wasps. Bulletin of the U.S. National Museum 143: 351.

Pitts JP, Manley DG. 2004. A revision of Lomachaeta Mickel, with a new species of Smicromutilla Mickel (Hymenoptera: Mutillidae). Zootaxa 474: 1-27.

Triplehorn CA, Johnson NF. 2005. Family Mutillidae. In Borror and Delong's Introduction to the Study of Insects, 7th ed. Thomson Brooks/Cole, Belmont, CA.

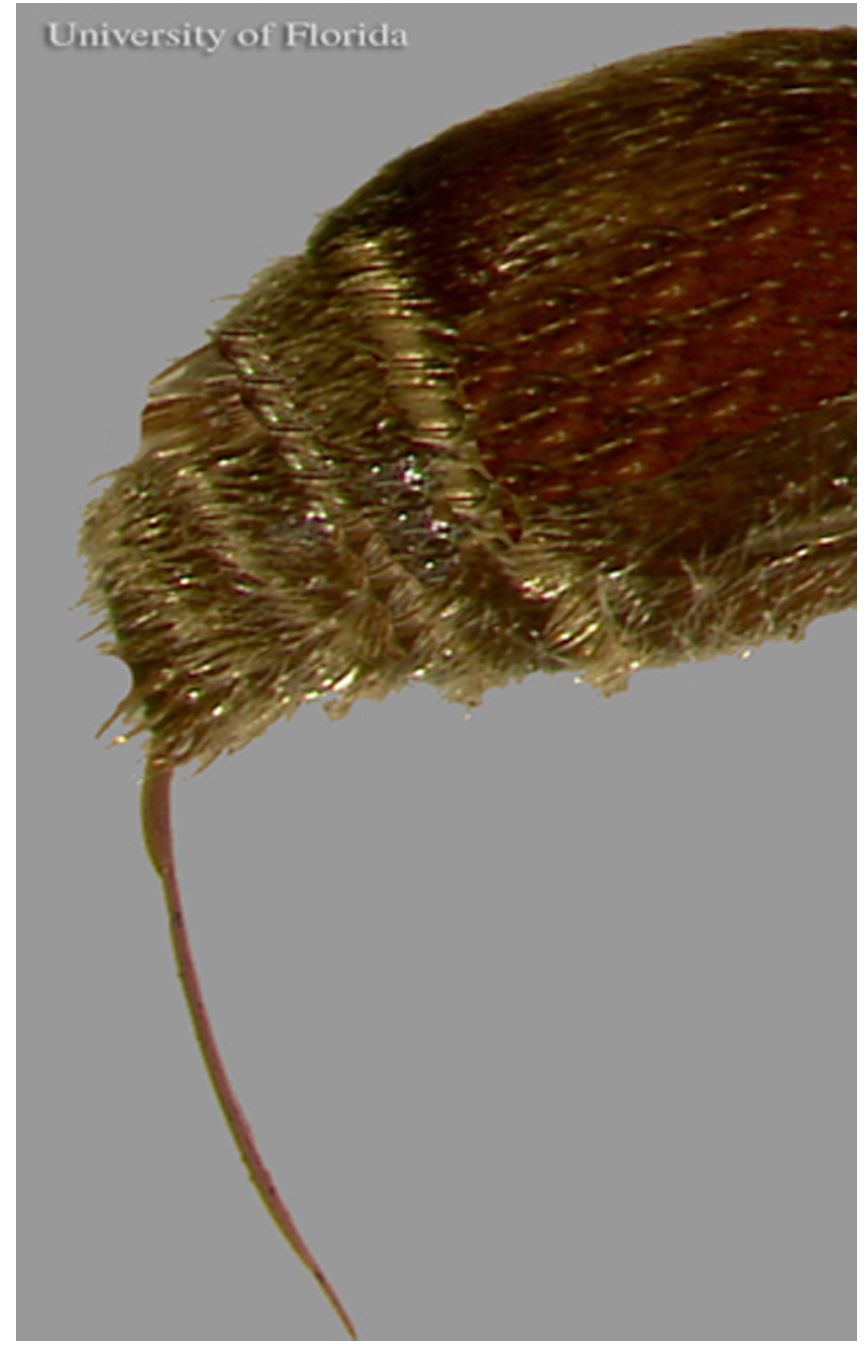

Figure 41. Ovipositor (stinger) of an unidentified, adult female velvet ant, Dasymutilla sp. Credits: Jeffrey C. Hertz, University of Florida 